\title{
Artikel
}

\section{Crisis in het profvoetbal}

\author{
Verlagen van het salaris: een (no-)go?
}

Tim Wilms en Niels Jansen*

\section{Inleiding}

Met het voortijdig beëindigen van de Nederlandse betaald voetbalcompetities in seizoen 2019/2020 en de afwezigheid van publiek in de voetbalstadions voor meer dan een jaar, werd de voetbalsector sportief en financieel zwaar getroffen door de coronacrisis. Het seizoen 2019/2020 eindigde zonder landskampioen en inkomsten van de clubs, met name afhankelijk van publiek bij wedstrijden, vielen door de coronabeperkingen grotendeels weg. De crisis leidde ertoe dat clubs genoodzaakt waren financiële maatregelen te treffen, waaronder afspraken met seizoenkaarthouders, sponsors en partners over continuering van de samenwerking en betalingen. Hoewel deze niet altijd toereikend waren voor met name eredivisieclubs - het gemiddelde salaris van de speler uit de eredivisie ligt immers boven het maximumsalaris dat wordt meegenomen in de subsidieberekening van de $\mathrm{NOW}^{1}$ - werd er niettemin door veel voetbalclubs gebruikgemaakt van de NOW-subsidie. ${ }^{2}$

* Mr. T.A. (Tim) Wilms is advocaat arbeidsrecht en sport bij Kennedy Van der Laan. Mr. dr. N. (Niels) Jansen is universitair docent arbeidsrecht aan de Universiteit van Amsterdam. De auteurs zijn tevens redactielid van het tijdschrift Voetbal- \& Sportjuridische Zaken.

1. Bij de berekening van de NOW-subsidie wordt uitgegaan van een maximumsalaris van EUR 9.538 bruto per maand, terwijl het gemiddelde salaris van de eredivisie speler in 2019 nog EUR 24.250 bruto per maand (EUR 291.000 per jaar) zou bedragen volgens onderzoek van de FBO (zie: https://vi.nl/nieuws/gemiddeld-salaris-eredivisie-stijgt-naar291-duizend-euro)

2. De registers met daarin de genoemde NOW-subsidies zijn gepubliceerd op de website van het UWV. Zie verder o.a.: https://trouw.nl/sport/ betaald-voetbal-krijgt-dertig-miljoen-uit-now-pot-vier-miljoen-daarvanis-voor-ajax ba354e3a/; https://nos.nl/artikel/2357096-tweede-now-
Op sectorniveau werden door alle bij de sector betrokken actoren, waaronder de clubs en de spelers, aan het begin van de coronacrisis tijdelijke afspraken gemaakt over onder meer de wijze waarop spelerssalarissen verlaagd zouden moeten worden. Een 'uniek akkoord' werden de afspraken genoemd. ${ }^{3}$ En ondanks dat zo'n kwalificatie altijd direct de vraag oproept in hoeverre 'uniek' ook echt uniek is, moet gezegd worden dat een salarisreductie van EUR 35 miljoen op jaarbasis zonder meer uitzonderlijk te noemen is.

De aanbevelingen met betrekking tot de salarisreductie liepen tot 1 januari 2021 en hoewel het einde van de crisis toen nog niet in zicht was, zijn de aanbevelingen niet verlengd. In plaats van een nieuwe collectieve regeling, gingen een aantal clubs (door omstandigheden gedwongen) hun eigen weg en kozen zij ervoor met spelers nieuwe afspraken te maken over verlaging van salarissen na 1 januari 2021. Dat salarisverlaging een gevoelig onderwerp kan zijn en een zorgvuldige benadering vergt, blijkt wel uit de ophef die ontstond rondom de door Feyenoord aangekondigde anvullende verlaging van spelerssalarissen in februari van dit jaar. ${ }^{4}$ Feyenoord trachtte de verlaging eenzijdig door te voeren zonder instemming van de spelers.

In dit artikel analyseren wij hoe in de voetbalsector op de crisis is gereageerd en welke keuzes daarbij zijn gemaakt en dan met name op het terrein van salarisverlagingen. We bespreken uiteraard het juridisch kader omtrent salarisverlaging en onderzoeken of, en zo ja, in

steun-bijna-20-miljoen-euro-naar-eredivisieclubs-psv-koploper; https:// nos.nl/collectie/13840/artikel/2369865-helft-minder-now-steuneredivisieclubs-dan-vorige-periode-11-miljoen.

3. https://fbo.nl/2020/05/07/uniek-akkoord-betaald-voetbal/.

4. Zie bijv.: https://nos.nl/artikel/2369740-vvcs-boos-over-tweede-loon offer-feyenoord-totaal-verkeerde-handelwijze. 
welke mate voetbalclubs in crisistijd van hun voetballers kunnen verlangen dat zij genoegen nemen met salarisvermindering. We besteden daarbij specifiek aandacht aan de verhouding tussen wijzigingen van arbeidsvoorwaarden die steun vinden in sectorale collectieve afspraken en wijzigingen die deze steun ontberen, waarbij ook de invloed van (het ontbreken van) collectieve afspraken op de juridische toelaatbaarheid van wijzigingen aan de orde komt.

\section{Collectief akkoord omtrent salarisverlaging tussen vakbonden en werkgeversorganisatie}

Op 7 mei 2020 kondigden de werkgeversorganisatie in de betaald voetbal-sector Federatie Betaald Voetbal Organisaties (FBO) en vakbonden ProProf en VVCS samen met de vakorganisatie Coaches Betaald Voetbal aan dat er een 'uniek' collectief akkoord was bereikt tussen alle betrokken partijen in de sector. Dit akkoord zag op een pakket aan 'noodmaatregelen' voor het betaald voetbal ter beperking van de negatieve gevolgen van de COVID-19 pandemie. $^{5}$ Partijen hadden een akkoord bereikt met collectieve aanbevelingen en bindende afspraken.

18 De aanbevelingen zagen op het resterende deel van seizoen 2019/2020 en de eerste seizoenshelft van het seizoen 2020/2021 en hadden betrekking op een salarisverlaging voor spelers van betaald voetbalclubs. De salarisverlaging was gebaseerd op een progressieve staffel. Deze staffel begon vanaf $2,5 \%$ voor jaarsalarissen van meer dan EUR 25.000 bruto per jaar en liep op tot maximaal 20\%. Vanaf een jaarsalaris van EUR 500.000 zou de salarisverlaging $20 \%$ dienen te bedragen. ${ }^{6}$ De aanbeveling ten aanzien van de salarisreductie gold tot 1 januari 2021 en voor de periode daarna zijn (ook later) geen nieuwe of aanvullende afspraken meer gemakt. De overige aanbevelingen betroffen (i) het afzien van, dan wel het vinden van een minnelijke regeling ten aanzien van uitbetaling van collectieve bonussen; (ii) het afzien van eventuele resterende vakantiedagen over het seizoen 2019/2020; en (iii) de mogelijkheid tot betaling van de vakantietoeslag over het seizoen 2019/2020 in de maand juni in plaats van de maand mei. Hoewel het collectief overleg over arbeidsvoorwaarden veelal uitmondt in een partijen (en individuele leden) bindende cao, kreeg het akkoord in de voetbalsector niet de status van cao. Het gevolg hiervan is dat de in de sector geldende CAO voor Contractspelers inhoudelijk ongewijzigd bleef en dat de aanbevelingen op het terrein van arbeidsvoorwaarden niet bindend waren voor individuele spelers en clubs. De clubs dienden daarom separaat (en niet strijdig met

5. https://fbo.nl/2020/05/07/uniek-akkoord-betaald-voetbal/.

6. https://vi.nl/nieuws/van-de-nederlandse-profs-verdient-38-procentminder-dan-het-modale-loon. de cao) met de individuele spelers overeenstemming zien te bereiken over salarisverlaging (zie verder hierna, par. 3). Voor zover bekend zijn de meeste clubs op basis van de aanbeveling met de spelers in onderhandeling getreden over de salarisverlaging en hebben (de meeste van hen) ook overeenstemming hierover met de spelers bereikt. $^{7}$

Naast aanbevelingen bevatte het akkoord ook bindende afspraken tussen FBO en de vakbonden. Deze afspraken zagen op (i) het tussentijds openbreken en verlengen van de CAO voor Contractspelers Betaald Voetbal van 1 juli 2020 tot en met 30 juni 2023 (en niet op een inhoudelijke wijziging), (ii) een verlaging van het verplichte aantal contractspelers in de Eerste Divisie, (iii) een verlaging van de toetsingsgrens betreffende de vakantietoeslag voor contractspelers, (iv) het door de spelersvakbonden afzien van een verhoging van de werkgeversbijdrage per 1 januari 2021 en (v) het, indien mogelijk, gelijk houden van het inkomenscriterium voor niet-EU spelers.

\section{Juridisch kader wijziging arbeidsovereenkomst}

De Nederlandse wet bevat op het terrein van arbeidsvoorwaarden niet veel meer dan minimumregelingen ten aanzien van bijvoorbeeld loon, vakantie, verlof en arbeidstijden. Arbeidsvoorwaarden komen in Nederland veelal tot stand door onderhandelingen op collectief en individueel niveau. De cao is een belangrijke rechtsbron in het arbeidsrecht omdat een cao dwingend kan doorwerken in individuele arbeidsovereenkomsten en zodoende in belangrijke mate de arbeidsvoorwaarden van grote groepen werkenden bepaalt en de individuele onderhandelingspositie begrenst. Zonder in de details van het cao-recht te treden, kan niet zonder meer ten nadele van werknemers worden afgeweken van geldende cao-bepalingen. Via het cao-overleg kunnen werknemers en werkgevers op gelijkwaardige wijze onderhandelen over arbeidsvoorwaarden. Cao's dragen daarmee bij aan arbeidsrust, sociale rechtvaardigheid, rechtszekerheid en stabiele arbeidsverhoudingen. ${ }^{8}$ Wijzingen van arbeidsvoorwaarden vinden in Nederland veelal plaats via het cao-overleg.

Zoals in de vorige paragraaf al benoemd, hebben de collectieve aanbevelingen in de voetbalsector geen kracht van cao gekregen en is de CAO voor Contractspelers inhoudelijk niet gewijzigd. Dit brengt mee dat het voor de betaald voetbalclub niet voldoende is om met een beroep op de aanbeveling een salarisverlaging op individueel niveau (club vs. speler) door te voeren.

7. Zie bijv.: https://nos.nl/collectie/13840/artikel/2334400-psv-bereiktakkoord-met-spelers-over-salarisoffer; https://willem-ii.nl/artikel/ak koord-over-tijdelijke-salarisverlaging; https://ad.nl/nederlands-voetbal/ selectie-en-directie-ajax-akkoord-met-inleveren-salaris a958dd47/.

8. Zie hierover meer: N. Jansen, Een juridisch onderzoek naar de representativiteit van vakbonden in het arbeidsvoorwaardenoverleg, Deventer: Kluwer 2019 
Salaris is een primaire arbeidsvoorwaarde en primaire arbeidsvoorwaarden kunnen buiten de cao en het caorecht slechts onder voorwaarden worden gewijzigd (waarbij geldt dat een wijziging niet in strijd met de cao mag zijn). Wijziging van een primaire arbeidsvoorwaarde is in beginsel slechts mogelijk met instemming van de werknemer. Hierbij geldt dat de werkgever er slechts op mag vertrouwen dat een werknemer heeft ingestemd met een voor hem nadelige wijziging van zijn arbeidsvoorwaarden als hem duidelijkheid is verschaft over de inhoud van die wijziging en op basis van verklaringen of gedragingen van die werknemer een welbewuste instemming met de wijziging mag worden aangenomen. ${ }^{9}$ Als de werknemer niet instemt met de salarisverlaging, dient te worden beoordeeld of de werkgever eenzijdig op basis van een wettelijke grondslag kan overgaan tot wijziging van de arbeidsvoorwaarde. Hierbij zijn verschillende wettelijke grondslagen te onderscheiden: wijziging op grond van een eenzijdig wijzigingsbeding als bedoeld in artikel 7:613 BW, artikel 7:611 BW (goed werkgeverschap), redelijkheid en billijkheid ex artikel 6:248 lid 2 BW, of onvoorziene omstandigheden ex artikel 6:258 $\mathrm{BW}$. Hieronder zullen deze grondslagen kort uiteen worden gezet.

Voor eenzijdige wijziging op grond van artikel 7:613 $\mathrm{BW}$ is vereist dat er een schriftelijk eenzijdig wijzigingsbeding is overeengekomen tussen werkgever en werknemer dat de werkgever de bevoegdheid geeft een in de arbeidsovereenkomst voorkomende arbeidsvoorwaarde te wijzigen. Als dat het geval is, moet worden getoetst of de werkgever in het concrete geval gebruik mag maken van dat beding. Artikel 7:613 BW bepaalt dat de werkgever een beroep op dit beding kan doen indien hij bij de wijziging van de arbeidsovereenkomst een zodanig zwaarwichtig belang heeft dat het belang van de werknemer dat door de wijziging zou worden geschaad, daarvoor naar maatstaven van redelijkheid en billijkheid moet wijken. Volgens de wetgever kan van zwaarwichtige omstandigheden worden gesproken bij zwaarwegende bedrijfseconomische of organisatorische omstandigheden waaronder het in grote financiële moeilijkheden verkeren. ${ }^{10} \mathrm{Bij}$ de toets of een werkgever de eenzijdige wijziging mag doorvoeren op grond van dit artikel dient een belangenafweging plaats te vinden, waarbij volgens de Hoge Raad het vereiste gewicht van de belangen van de werkgever mede wordt bepaald door het gewicht van de belangen van de werknemer die daartegenover staan. ${ }^{11}$ Hoewel de Hoge Raad in het arrest Stoof/Mammoet heeft aangegeven dat artikel 7:613 BW 'veeleer' ziet op collectieve wijzigingen van de arbeidsovereenkomst, lijkt dit artikel - ondanks dat daarover discussie bestaat in de literatuur - ook te kunnen worden toegepast in individuele gevallen waarin de werkgever de arbeidsovereenkomst wil wijzigen. ${ }^{12} \mathrm{De}$

9. HR 12 februari 2010, ECLI:NL:HR:2010:BK3570 (CZ). Zie ook: HR 23 november 2018, ECLI:NL:HR:2018:2185

10. Kamerstukken II 1995/96, 24615, nr. 3, p. 24

11. HR 29 november 2019, ECLI:NL:HR:2019:1864 (Fair Play).

12. Zie o.a. W.A. Zondag, art. 7:613 BW, aant. 4.1, in: Sdu Commentaar Arbeidsrecht Thematisch, Den Haag: Sdu 2021, en voor toepassing van opmerking van de Hoge Raad lijkt hoofdzakelijk bedoeld om aan te geven dat de wetgever artikel 7:613 BW heeft ingevoerd met het oog op collectieve gevallen waarin bedrijfseconomische omstandigheden nopen tot een wijziging van arbeidsvoorwaarden van meerdere werknemers en niet als een oordeel dat artikel 7:613 BW niet in individuele gevallen kan worden toegepast. ${ }^{13}$

Bij het ontbreken van een wijzigingsbeding zal de werkgever noodzakelijkerwijs met alle individuele werknemers in onderhandeling moeten treden over de voorgenomen wijziging. Op grond van de Hoge Raad-arresten Van der Lely/Taxi Hofman $B V^{14}$ en Stoof/ Mammoet ${ }^{15}$ - die het toetsingskader van artikel 7:611 bij wijziging van de arbeidsovereenkomst verder uitwerken - kan op grond van het goed werknemerschap van de werknemer onder omstandigheden de bereidheid worden verlangd mee te werken aan aanpassing van zijn arbeidsovereenkomst op verzoek van werkgever. Er zijn drie stappen die hierbij moeten worden doorlopen: (i) Is er sprake van gewijzigde omstandigheden die nopen tot een wijziging van de overeenkomst? (ii) Is het gedane voorstel van werkgever tot wijziging van de overeenkomst in het licht van alle omstandigheden van het geval redelijk? En (iii): kan aanvaarding van het voorstel in redelijkheid van de werknemer worden gevergd? ${ }^{16}$ Als aan deze voorwaarden is voldaan, kan de werknemer - als goed werknemer - het voorstel van de werkgever niet weigeren. Als hij toch weigert, leidt die weigering overigens niet tot wijziging van de arbeidsovereenkomst van rechtswege. De werkgever zal voor de wijziging dan in beginsel in rechte moeten afdwingen dat de werknemer instemt met de wijziging. Als de werkgever in plaats daarvan en dus zonder dit eerst aan de rechter voor te leggen, overgaat tot wijziging, zal de werknemer een procedure dienen te beginnen waarbij hij nakoming van de ongewijzigde arbeidsovereenkomst vraagt. In beginsel zou de rechter zo'n vordering moeten toekennen omdat geen wijziging tot stand is gekomen, ${ }^{17}$ maar in de praktijk lijken rechters werkgevers tegemoet te komen door op grond van de Stoof/Mammoet-toets te beoordelen of de werknemer op grond van goed werknemerschap aanspraak kan maken op de vorderingen. ${ }^{18}$

Ook op artikel 6:248 lid 2 BW, de derogerende werking van de redelijkheid en billijkheid, zou de werkgever een beroep kunnen doen voor de eenzijdige wijziging van de arbeidsovereenkomst. Dit artikel bepaalt dat een tussen partijen overeengekomen geldende voorwaarde niet van toepassing is voor zover dit gegeven de omstandigheden

art. 7:613 BW in individuele gevallen in lagere rechtspraak o.a.: Hof Arnhem-Leeuwarden 21 juli 2015, ECLI:NL:GHARL:2015:5452; Rb. Alkmaar 24 maart 2009, JAR 2009/149.

13. W.A. Zondag, art. 7:613 BW, aant. 4.1, in: Sdu Commentaar Arbeidsrecht Thematisch, Den Haag: Sdu 2021.

14. HR 26 juni 1998, JAR 1998/199 (Van der Lely/Taxi Hofman).

15. HR 11 juli 2008, JAR 2008/204 (Stoof/Mammoet).

16. E. Verhulp, art. 7:613, aant. 6, in Tekst \& Commentaar Arbeidsrecht, Deventer: Wolters Kluwer 2020.

17. Zie bijv. Rb. Zeeland-West-Brabant 30 januari 2017, ECLI:NL:RBZWB 2017:932.

18. Zie bijv. Rb. Rotterdam 31 december 2020, ECLI:NL:RBROT: 2020:13091. 
naar maatstaven van redelijkheid en billijkheid onaanvaardbaar zou zijn. Voorts kan een werkgever ook de rechter verzoeken de arbeidsovereenkomst te wijzigen op grond van onvoorziene omstandigheden als bedoeld in artikel 6:258 BW. De onvoorziene omstandigheden dienen dan van dien aard te zijn dat de wederpartij naar maatstaven van redelijkheid en billijkheid ongewijzigde instandhouding van de arbeidsovereenkomst niet mag verwachten. Wij zullen in dit artikel met name op eenzijdige wijziging op grond van het eenzijdig wijzigingsbeding en goed werkgeverschap ingaan, omdat deze gronden het meest worden gebruikt bij een beroep op eenzijdige wijziging. De overige gronden zullen wij verder niet in detail bespreken.

Welke invloed de instemming (of juist het ontbreken daarvan) van vakbonden, ondernemingsraden of de meerderheid van de werknemers heeft op de juridische beoordeling van een door de werkgever gewenste wijziging bespreken we in paragraaf 5 .

\section{Rechtspraak omtrent eenzijdige wijziging van salaris}

In deze paragraaf zal eenzijdige salariswijziging in het algemeen - los van de grondslag - worden besproken. Wij zullen hierbij niet ingaan op de vraag of de toetsing van artikel 7:613 BW en artikel 7:611 even zwaar zijn, maar op grond van de rechtspraak lijken er aanknopingspunten dat deze toetsing gelijk dan wel vergelijkbaar is. ${ }^{19}$

In de gepubliceerde rechtspraak zijn slechts enkele uitspraken te vinden waarin een werkgever eenzijdig het salaris van werknemer(s) mocht verlagen en de wijzigingstoets dus slaagde. Hof Den Bosch oordeelde in 2012 dat een werkgever zijn chauffeurs in een lagere functieschaal mocht indelen met een lager salaris. ${ }^{20} \mathrm{De}$ chauffeurs waren oorspronkelijk ingedeeld in een functieschaal die aansloot bij hun functie als chauffeur van internationale ritten. Bij de werkgever was echter sprake van een absolute afname van internationale ritten en waren voor de werknemers geen internationale ritten meer beschikbaar. De van toepassing zijnde cao bepaalde dat langdurig belast zijn met werkzaamheden verbonden aan een lager gewaardeerde functie, mocht leiden tot salarisverlaging via een afbouwregeling. Het hof liep de drie stappen van het Stoof/Mammoet-arrest af en oordeelde dat aan de toets was voldaan, waardoor de werkgever de chauffeurs mocht terugzetten in functie en het salaris mocht verlagen. Relevant hierbij was met name dat het salarisverlies werd omgezet in een persoonlijke toeslag die vervolgens werd afgebouwd.

19. Zie conclusie A-G Drijber, ECLI:NL:PHR:2019:645 en Hof 's-Hertogenbosch 20 november 2012, RAR 2013/11 met Wenk.

20. Hof 's-Hertogenbosch 20 november 2012, ECLI:NL:GHSHE:2012: BY4057.

Kantonrechter Utrecht stond een eenzijdige opgelegde collectieve salarisverlaging van 6\% (3\% per 1 juni 2013 en $3 \%$ per 1 januari 2014) toe op grond van de Stoof/ Mammoet-toets in een zaak in 2013 waarbij de ondernemingsraad positief had gereageerd op de wijziging en het grootste gedeelte van de werknemers (78 werknemers tegen 16) had ingestemd met de wijziging. ${ }^{21} \mathrm{De}$ belangen van de werkgever zagen erop dat hij door de financiële crisis veel mensen dreigde te moeten ontslaan en met de salarisverlaging kon voorkomen dat de bank het krediet opzegde. De kantonrechter merkte nog op dat de salarisverlaging voor de (enkele) werknemer die de procedure aanhangig had gemaakt relatief beperkt was met een totaal van EUR 195 bruto per maand. Over de waardering van dat belang kun je anders denken.

Daarnaast is er een (groter) aantal zaken waarin een eenzijdig collectieve salarisverlaging niet werd toegestaan door de rechter. Het mogelijk bekendste voorbeeld is de procedure tussen vakbonden FNV en CNV en Vroom \& Dreesmann B.V. (V\&D) uit 2015. ${ }^{22}$ V\&D kampte met forse verliezen en wenste onder meer de salarissen van haar werknemers met 5,8\% te verlagen in twee jaar tijd. V\&D stelde daarbij dat zijn loonkosten ruim $(13,2 \%)$ hoger lagen dan de loonkosten in de branche en dat de voorgenomen salarisverlaging ertoe zou leiden dat V\&D weer winst zou gaan behalen. Volgens de rechtbank rechtvaardigde de financiële situatie van V\&D dat V\&D trachtte een kostenreductie te realiseren en was daarmee voldaan aan de eerste stap uit het Stoof/Mammoetarrest. Volgens de rechtbank zou het accepteren van een dusdanige substantiële salarisverlaging echter op gespannen voet staan met het wettelijk systeem van arbeidsrechtelijke bescherming waardoor niet werd voldaan aan de tweede en derde stap van het Stoof/ Mammoet-arrest. De rechtbank achtte daarbij relevant dat het onroerend goed van V\&D recent voor een groot bedrag was verkocht en V\&D niet duidelijk kon maken waarvoor de opbrengst van die verkoop was aangewend. De rechtbank verwees ook naar de bovengenoemde uitspraak van kantonrechter Utrecht en stelde dat die zaak niet vergelijkbaar was, omdat daar de ondernemingsraad de maatregelen steunde en V\&D geen akkoord met vakbonden of ondernemingsraad had. De salarisverlaging doorstond de toets van artikel 7:611 BW derhalve niet. ${ }^{23}$ Terzijde merkte de rechtbank op dat dit oordeel onverlet liet dat de werknemers, al dan niet verenigd via de vakbonden, alsnog zouden kunnen instemmen met een salarisverlaging als daarmee viel te verwachten dat dit de bestaanszekerheid van het bedrijf, en daarmee de werkgelegenheid daarbinnen, ten goede zou komen. Hiermee verwees de rechtbank V\&D in principe terug naar het collectief overleg met de vakbonden en werknemers.

Tot een vergelijkbaar oordeel kwam de rechtbank Overijssel in 2015 in een geschil tussen thuiswerkorganisatie

Rb. Utrecht 13 december 2013, ECLI:NL:RBMNE:2013:7414 Rb. Amsterdam 23 februari 2015, ECLI:NL:RBAMS:2015:899.

V\&D had ook een beroep op artikel 6:248 lid 2 BW gedaan, maar de rechtbank oordeelde dat dit niet kon slagen omdat deze toets minstens even streng is als die van artikel 7:611 BW. 
TSN en 109 van haar werknemers. TSN werd het (in zeven separate kort gedingen) verboden de salarissen van de werknemers ${ }^{24}$ op grond van artikel 7:611 BW te verlagen, ondanks dat de rechtbank erkende dat TSN in financieel zwaar weer verkeerde. ${ }^{25}$ In deze zaak achtte de rechtbank doorslaggevend dat de teruggang in salaris aanzienlijk was, de eisers zich in de onderste regionen van het salarisgebouw bevonden, zij in financieel slecht weer zouden kunnen komen door de salarisverlaging en er een slechts beperkte afbouwregeling was aangeboden. Ook sinds de uitbraak van de COVID-19-pandemie lijkt een (tijdelijk) loonoffer, met een beroep op de gevolgen van deze pandemie, nog steeds geen gemakkelijk te nemen horde. Rechtbank Amsterdam oordeelde dat de buitengewone omstandigheden - de sluiting van het bedrijf van werkgever - aanleiding zouden kunnen geven om van werknemers een loonoffer te verlangen, maar dat in die specifieke zaak een broodjeszaak het loon van een werknemer niet met 50\% mocht opschorten gedurende meerdere maanden. ${ }^{26}$ Recent oordeelde rechtbank Rotterdam dat een werkgever als gevolg van COVID-19 de in een cao opgenomen loonsverhogingen mocht uitstellen op grond van artikel 7:613 BW, maar niet de vakantie-uren mocht laten vervallen. In de procedure was onbetwist gebleven dat de werkgever (forse) liquiditeitsproblemen had en de werkgever ook al diverse andere maatregelen had genomen om deze te verminderen (onderhandelen met haar verhuurder, uitstellen van investeringen, aanvragen van een NOWvoorschot en vragen van een loonoffer aan de directie). De rechtbank oordeelde dat voor wat betreft het uitstellen van loonsverhoging een belangenafweging tot de conclusie leidde dat de acute financiële problemen die de werkgever ondervond door de coronapandemie een zodanig zwaarwichtig belang vormen dat de belangen van de werknemers daarvoor naar maatstaven van redelijkheid dienden te wijken. Daarbij speelde mee dat werknemers een deel van de loonsverhoging die per april 2020 zou worden ingevoerd reeds per december 2019 hadden ontvangen en dat het geen permanente wijziging betrof, maar een eenmalige, tijdelijke maatregel, alsmede dat de ondernemingsraad, na raadpleging van een deskundige, had ingestemd met de maatregelen. Het laten vervallen van vakantie-uren was op grond van artikel 7:613 BW geen toelaatbare eenzijdige wijziging. De rechtbank oordeelde dat het recht op vakantie immers een belangrijke arbeidsvoorwaarde is en dat de werknemers recht hebben op recuperatie om hun werk optimaal te kunnen blijven verrichten.

Volgens de eisers (werknemers) wenste TSN het salaris met $20-25 \%$ te verlagen.

25. Rb. Overijssel 13 november 2015, ECLI:NL:RBOVE:2015:5017; ECLI: NL:RBOVE:2015:5041; ECLI:NL:RBOVE:2015:5046; ECLI:NL:RBOVE: 2015:5045; ECLI:NL:RBOVE:2015:5043; ECLI:NL:RBOVE:2015:5044.

26. Rb. Amsterdam 20 mei 2020, ECLI:NL:RBAMS:2020:2734.

\section{De rol van collectief overleg in het licht van de zware toets van eenzijdige wijziging van het salaris}

Overeenstemming is in het Nederlandse recht de 'koninklijke' route om arbeidsvoorwaarden te wijzigen. Die overeenstemming kan worden bereikt op collectief niveau via bijvoorbeeld cao-afspraken of - bij gebreke van een cao - via het overleg met individuele werknemers. De contractsvrijheid is een belangrijk uitgangspunt in het Nederlandse recht en die vrijheid brengt mee dat een werkgever zelf kan kiezen of hij op collectief of individueel niveau gaat onderhandelen over de wijziging van arbeidsvoorwaarden. Anders gezegd, werkgevers die arbeidsvoorwaarden willen wijzigen, zijn niet verplicht daarover eerst met een vakbond te onderhandelen. Werkgevers mogen die onderhandelingen ook direct op individueel niveau voeren. Het voorgaande laat onverlet dat werkgevers bestaande collectieve afspraken (en daarmee de bestaande verhoudingen) wel zullen moeten respecteren. Het staat een aan de cao gebonden werkgever op grond van het cao-recht namelijk niet steeds vrij om arbeidsvoorwaarden in overleg met een werknemer te wijzigen als de voorgenomen wijziging in strijd is met de cao. Deze hiërarchische verhouding tussen enerzijds de cao en anderzijds de individuele arbeidsovereenkomst brengt mee dat werkgevers die arbeidsvoorwaarden van het personeel willen wijzigen, veelal eerst in overleg treden met de vakorganisaties. Als een akkoord tot stand komt (dat kan worden aangemerkt als cao), heeft dat als bijkomend voordeel dat een werkgever in beginsel niet ook nog eens op individueel niveau hoeft te onderhandelen omdat werknemers in beginsel zullen zijn gebonden aan de cao-voorwaarden en dat levert zonder meer ook transactiewinst op.

Wanneer vakbonden instemmen met een door de werkgever wenselijk geachte wijziging en deze wijziging wordt vastgelegd in een cao, dan wordt deze wijziging in de rechtspraak veelal beschouwd als tweezijdige wijziging (waaraan een werknemer dan ook veelal gebonden is). ${ }^{27}$ Volgens rechtbank Oost-Brabant ligt aan dit oordeel onder meer ten grondslag dat met de betrokkenheid van vakbonden de rechtsbescherming van werknemers voldoende is gewaarborgd. ${ }^{28}$ Deze overweging ligt overigens in het verlengde van de overweging van de Hoge Raad in het arrest TPG/Bollemeijer dat aangenomen moet worden dat in de bescherming van de werknemer is voorzien doordat vakorganisaties betrokken zijn geweest. ${ }^{29}$ De aanwezigheid van een verenigingsstructuur (lees: vakbond) is voor rechters kennelijk al snel een reden om te oordelen dat het met de belan-

27. Zie bijv. Rb. Den Haag 29 mei 2019, JIN 2019/174; Hof Amsterdam 19 februari 2019, ECLI:NL:GHAMS:2019:479; Rb. Oost-Brabant 11 juli 2019, ECLI:NL:RBOBR:2019:4039.

28. Rb. Oost-Brabant 11 juli 2019, ECLI:NL:RBOBR:2019:4039, r.o. 4.5.2

29. HR 20 december 2002, ECLI:NL:HR:2002:AF2166. 
genbehartiging van individuele werknemers wel goed zit. Deze lijn dient naar onze mening ook te worden doorgetrokken naar de situatie waarin bij een wijziging van arbeidsvoorwaarden een vakbond betrokken wordt, maar die betrokkenheid niet leidt tot een cao, en een werkgever vervolgens met individuele werknemers gaat onderhandelen over de wijziging van arbeidsvoorwaarden. Denk hierbij concreet aan de aanbevelingen die partijen in de voetbalsector zijn overeengekomen en niet de status van cao hebben. Wanneer werkgever en werknemer in de onderhandelingen niet tot overeenstemming komen over de door de vakbonden akkoord bevonden of aanbevolen wijziging van arbeidsvoorwaarden, is de vraag of eenzijdige wijziging van de arbeidsvoorwaarden door de werkgever op basis van één van de grondslagen besproken in paragraaf 3 is toegestaan. Naar onze mening is in die situatie de instemming van de vakbonden met de wijziging (hoewel dus niet vastgelegd in een cao) een (zeer) zwaarwegend belang in de wijzigingstoets in het voordeel van werkgever.

Uit de rechtspraak volgt verder dat wanneer het 'instemmende' collectief slechts wordt gevormd door de meerderheid van het personeel (en een verenigingsstructuur dus ontbreekt), rechters in de regel niet al te veel waarde lijken te hechten aan de instemming van die meerderheid van het personeel. ${ }^{30}$ In een zaak uit 2013 oordeelde kantonrechter Zutphen bijvoorbeeld dat de omstandigheid dat $69 \%$ van de meerderheid had ingestemd met een voorstel, niet meebracht dat de rechtspositie van werknemers die niet hadden ingestemd daardoor diende te worden beïnvloed. ${ }^{31}$ Ook wanneer de ondernemingsraad instemt met een wijziging, blijkt dat voor rechters geen reden om individuele werknemers te houden aan een wijziging. Uit het Fair Play Centersarrest volgt dat de instemming van de ondernemingsraad niets meer is dan een (belangrijk) gezichtspunt bij de wijzigingstoets. ${ }^{32}$ Welke waarde aan de instemming van het collectief moet worden gehecht bij de toepassing van de wijzigingstoets in een individueel geval, lijkt dus veelal afhankelijk te zijn van de samenstelling van dit collectief.

Het voorgaande leidt tot de conclusie dat de aanbevelingen die in de voetbalsector zijn overeengekomen over de salarisverlagingen tussen onder meer de voetbalclubs en de spelersvakbond, van groot belang zullen zijn bij de toepassing van de wijzigingstoets in een individueel geval. Niet gewaagd lijkt in het licht hiervan de stelling dat individuele spelers die zich verzetten tegen de op collectief niveau overeengekomen aanbevelingen ten aanzien van de salarisverlagingen van goeden huize moeten komen. Die mogelijkheid tot verzet is er wel, maar dan zal een voetballer aannemelijk moeten maken dat de wijziging naar maatstaven van redelijkheid en billijkheid voor hem onaanvaardbaar is.

30. N. Jansen, Een juridisch onderzoek naar de representativiteit van vakbonden in het arbeidsvoorwaardenoverleg, Deventer: Kluwer 2019, p. 167.

31. Rb. Oost-Nederland 27 maart 2013, ECLI:NL:RBONE:2013:CA0060.

32. HR 29 november 2019, ECLI:NL:HR:209:1864 en HR 17 januari 2020, ECLI:NL:HR:2020:72
Hierbij speelt op de achtergrond een belangrijke rol dat het collectief overleg voor de voetbalsector van eminent belang is. Via dit collectief overleg is immers voor de voetbalsector een uitzondering op de ketenregeling ex artikel 7:668a en de gefixeerde schadevergoeding ex artikel 7:677 lid 4 BW gerealiseerd, waarmee het Nederlandse transfersysteem en daarmee de sector overeind wordt gehouden. Anders gezegd: zonder collectief overleg is er geen sector en daaraan is het individuele spelersbelang tot op zekere hoogte ondergeschikt.

Het voorgaande brengt voor voetbalclubs tegelijkertijd mee dat bij gebreke van een regeling op collectief niveau, niet eenvoudig tot wijziging van individuele arbeidsvoorwaarden kan worden gekomen. Sterker, de omstandigheid dat de aanbevelingen in de voetbalsector expliciet golden tot 1 januari 2021, lijkt een indicatie dat voor de periode na 1 januari 2021 een salarisverlaging van spelers juist niet in de rede ligt. Voetbalclubs die niettemin tot een salarisverlaging over 2021 willen overgaan, zullen daarvoor dus de instemming van individuele werknemers nodig hebben, want een eenzijdige wijziging lijkt wat ons betreft niet eenvoudig te realiseren. Een andere optie is, en dat lijkt ons zelfs de meest vruchtbare en redelijke weg, dat deze voetbalclubs de eigen organisatie van voetbalclubs $(\mathrm{FBO})$ proberen te bewegen opnieuw met de spelersvakbond in overleg te gaan over de verlenging van de eerdere aanbevelingen. Dat zal niet eenvoudig zijn, want voor een verlenging van de eerdere afspraken zijn twee welwillende partijen nodig en de spelersvakbond zal dat niet zomaar doen als dat niet in het belang van de sector en/of de spelers is. Als dan de vraag is of dat erg is, dan is het antwoord simpel. Nee, dat is niet erg en zelfs nodig teneinde blijvend te kunnen rechtvaardigen dat het wel goed zit met de bescherming van werknemers wanneer vakbonden betrokken zijn bij het collectief overleg. Die aanname geeft voetbalclubs juist ook enige zekerheid om te handelen zodra de vakbond wel heeft ingestemd met een wijziging. Dit klinkt wellicht wat collectivistisch, maar de geschiedenis heeft wel geleerd dat een sector tijdens een crisis gebaat is bij stabiele arbeidsverhoudingen en georganiseerd overleg.

\section{Conclusie}

In dit artikel hebben wij de mogelijkheden besproken waarin een voetbalclub kan overgaan tot vermindering van het salaris van een speler. De meest voor de hand liggende wijze en veilige route is met instemming van de speler. Uit de gepubliceerde rechtspraak volgt dat - wanneer een speler niet instemt met een salarisverlaging - het een voetbalclub vrijwel niet, althans niet snel is toegestaan om eenzijdig een verlaging door te voeren. De bescherming van het salaris van een werknemer hoeft immers niet snel te wijken voor het bedrijfseconomisch belang van de werkgever. Ook niet als een werkgever in financieel zwaar weer verkeert, getuige de in dit artikel besproken rechtspraak. Het salaris van de 
werknemer wordt simpelweg als een groot goed beschouwd. ${ }^{33}$ Eenzijdige salarisverlaging is kortom een (zeer) zware toets. Ook wanneer de spelersraad (of een medezeggenschapsorgaan van een club) en/of een groot deel van de overige spelers van een club heeft ingestemd met de salariswijziging zal dat voor een rechter niet snel een reden zijn om een eenzijdige salariswijziging in een specifiek geval toe te staan.

Het is in onze ogen echter wel voorstelbaar en begrijpelijk dat voetbalclubs in bepaalde omstandigheden (lees: in crisistijd) de mogelijkheid dienen te hebben om het salaris van werknemers te verlagen. Naar onze mening is daarbij een belangrijke rol weggelegd voor het collectief overleg met vakbonden. Wij pleiten voor het toekennen van een zwaarwegend belang aan de instemming van de vakbonden met een salarisverlaging, ook wanneer de afspraken met vakbonden ter zake salarisverlaging slechts 'aanbevelingen' zijn die niet zijn vastgelegd in een cao. Een voetballer die niet instemt met en zich wil verzetten tegen met de vakbonden op collectief niveau overeengekomen aanbevelingen ten aanzien van de salarisverlagingen, zal van goeden huize moeten komen en kan naar onze mening alleen ontkomen aan de salarisverlaging als hij aantoont dat deze naar maatstaven van redelijkheid en billijkheid voor hem onaanvaardbaar is. Als de speler dat niet kan aantonen ligt het voor de hand dat het de club is toegestaan eenzijdig het salaris van de speler te verlagen conform de collectieve afspraak op grond van één van de in paragraaf 3 besproken wettelijke grondslagen. Daartegenover staat dat wanneer er geen collectieve afspraken of aanbevelingen zijn over salarisverlaging, het voor een club vrijwel onmogelijk zal dienen te zijn, althans is, om zonder instemming van de speler (eenzijdig) tot salarisverlaging over te gaan. Het ligt kortom op de weg van (de vereniging van) clubs om in geval van een gewenste salarisverlaging hierover primair het overleg met vakbonden aan te gaan om tot collectieve afspraken te komen, zoals dat ook is gebeurd voor de periode tot 1 januari 2021.

Indien salarisverlaging op één van bovenstaande wijzen niet mogelijk blijkt, resteert voor clubs niets anders dan te zoeken naar alternatieve mogelijkheden tot kostenbesparing, waaronder bijvoorbeeld spelersverkoop, het aantrekken van huurspelers in plaats van werknemers en het opnemen van eenzijdige verlengingsopties in arbeidsovereenkomsten. Het reorganiseren binnen een voetbalselectie zal - ook met name in vergelijking met andere sectoren - in de praktijk waarschijnlijk lastig, zo niet onmogelijk, zijn. Dit omdat de algemene regels omtrent bedrijfseconomisch ontslag, zoals afspiegeling, lastig op een voetbalselectie toepasbaar zullen zijn en de profvoetbalsector zich bovendien kenmerkt door bepaalde tijdscontracten die niet tussentijds opzegbaar zijn, waardoor bij tussentijdse beëindiging in beginsel alsnog de restloonwaarde is verschuldigd door de club. Ook voor deze aangelegenheid zou overigens een rol kunnen zijn weggelegd voor het collectief overleg, nu de wetgever het toestaat dat bij cao van de dwingende regels bij bedrijfseconomisch ontslag wordt afgeweken en een speciale voor de sector ontwikkelde ontslagcommissie wordt aangesteld. ${ }^{34}$
33. In de vakliteratuur is zelfs betoogd dat eenzijdige wijziging van salaris per definitie moet zijn verboden, zie o.a.: N. Zekic, All is fair in love and crisis? Loonoffers en goed werknemerschap, Tijdschrift Arbeidsrechtpraktijk 2016/77.
34. Artikel 7:671a lid 2 jo. artikel 7:669 lid 6 BW. 